\title{
XPG gene rs751402 C>T polymorphism and cancer risk: Evidence from 22 publications
}

\author{
Haixia Zhou ${ }^{1, *}$, Ting-Yan Shi' ${ }^{2,}$, Wenwen Zhang ${ }^{3, *}$, Qiwen Li $^{3}$, Jinhong Zhu ${ }^{4}$, Jing \\ $\mathrm{He}^{1,5}$ and Jichen Ruan ${ }^{1}$ \\ ${ }^{1}$ Department of Hematology, The Second Affiliated Hospital and Yuying Children's Hospital of Wenzhou Medical University, \\ Wenzhou 325027, Zhejiang, China \\ ${ }^{2}$ Department of Obstetrics and Gynecology, Zhongshan Hospital, Fudan University, Shanghai 200032, China \\ ${ }^{3}$ State Key Laboratory of Oncology in South China, Department of Radiation Oncology, Sun Yat-sen University Cancer Center, \\ Collaborative Innovation Center for Cancer Medicine, Guangzhou 510060, Guangdong, China \\ ${ }^{4}$ Molecular Epidemiology Laboratory and Department of Laboratory Medicine, Harbin Medical University Cancer Hospital, \\ Harbin 150040, Heilongjiang, China \\ ${ }^{5}$ Department of Pediatric Surgery, Guangzhou Institute of Pediatrics, Guangzhou Women and Children's Medical Center, \\ Guangzhou Medical University, Guangzhou 510623, Guangdong, China \\ *These authors have contributed equally to this work \\ Correspondence to: Jichen Ruan, email: ruanjichen@163.com \\ Jing He, email: hejing198374@gmail.com
}

Keywords: DNA repair, XPG, polymorphism, cancer susceptibility, meta-analysis

Received: May 12, $2017 \quad$ Accepted: June 12, $2017 \quad$ Published: July 18, 2017

Copyright: Zhou et al. This is an open-access article distributed under the terms of the Creative Commons Attribution License 3.0 (CC BY 3.0), which permits unrestricted use, distribution, and reproduction in any medium, provided the original author and source are credited.

\section{ABSTRACT}

The Xeroderma pigmentosum group $G$ (XPG) gene promotes recognition and excision of damaged DNA during the DNA repair process. We conducted a comprehensive search of the MEDLINE, EMBASE, and Chinese Biomedical databases for publications evaluating the association XPG gene rs751402 C>T polymorphism and overall cancer risk. Pooled odds ratios (ORs) and $95 \%$ confidence intervals (CIs) were adopted to assess the strength of the association. A total of 22 publications encompassing 10538 cases and 10511 control subjects were included in the final meta-analysis. We found the polymorphism to be associated with increased cancer risk (TT vs. CC: $O R=1.18,95 \% C I=1.01-1.38, P=0.040 ; C T$ vs. $C C: O R=1.12,95 \%$ CI $=$ 1.01-1.24, $P=0.040$; and CT $/$ TT vs. CC: $O R=1.12,95 \% C I=1.002-1.26, P=0.045)$. Stratification by cancer type indicated that this polymorphism may increase the risk of gastric cancer and hepatocellular carcinoma, which was further confirmed by a falsepositive report probability analysis. Genotype-based mRNA expression provides further evidence that this polymorphism is associated with altered XPG MRNA expression. This meta-analysis suggests XPG gene rs751402 C>T polymorphism correlates with overall cancer risk, especially for gastric cancer and hepatocellular carcinoma.

\section{INTRODUCTION}

According to an estimation by GLOBOCAN, approximately 14.1 million new cancer cases, including 8.2 million deaths, occurred worldwide in 2012 [1]. Approximately 4,292,000 new cancer cases and 2,814,000 cancer deaths occurred in China in 2015, with lung, gastric, esophageal, and liver cancer being the most commonly diagnosed and the leading causes of death [2]. Risk factors for the leading causes of cancer-related deaths are tobacco consumption, overweight/obesity, physical inactivity, and infection [1]. Genetic factors should also be considered [3-8].

Human DNA repair genes maintain the integrity and stability of genomic DNA, consequently preventing carcinogenesis and influencing clinical outcomes $[9,10]$. 
Many genes promote the diverse DNA repair pathways, including the nucleotide excision repair (NER) pathway [11]. The NER pathway consists of damage recognition, demarcation, dual incision, and gap filling and can repair a variety of damaged DNA [12]. The NER pathway is the main mechanism for the removal of DNA adducts and lesions caused by chemical adducts [13]. Polymorphisms of the genes from the NER pathway might activate cancer risk alteration [14]. As one of the eight core genes in the NER pathway, Xeroderma pigmentosum group $\mathrm{G}(X P G)$, which is also known as excision repair cross-complementing group 5 (ERCC5), can recognize and excise DNA lesions on the 3 ' side to repair damaged DNA [15].

$X P G$ gene polymorphisms were reported to be associated with the susceptibility of various types of cancers [16-18]. Thus, most of the investigations were focused on rs $17655 \mathrm{G}>\mathrm{C}$ (Asp1104His). The association between $X P G$ gene rs751402 $\mathrm{C}>\mathrm{T}$ polymorphism (located at the $5^{\prime}$ untranslational region) and cancer risk has been investigated in several studies [19-40], but the findings were contradictory and inconclusive. Therefore, we performed this meta-analysis with all eligible publications to comprehensively evaluate the association of $X P G$ gene rs751402 $\mathrm{C}>\mathrm{T}$ polymorphism with overall cancer risk.

\section{RESULTS}

\section{Characteristics of eligible publications}

As shown in Figure 1, 227 publications were identified from MEDLINE and EMBASE and 26 additional publications in Chinese were identified from the Chinese Biomedical (CBM) database. After reviewing the abstracts and the full texts, we excluded 222 publications and selected 31 publications with studies of the rs 751402 $\mathrm{C}>\mathrm{T}$ polymorphism for further full-text review. Among these publications, nine were excluded because two studies were repetitive, five studies were clinical outcome studies, and two studies were not on cancers. In the final meta-analysis, 22 publications with studies of 10588 cases and 10511 control subjects were identified, with the duplicated samples counted only once. The characteristics of the included publications are showed in Table 1. In these publications, sample sizes ranged from 96 to 1900 cases and from 101 to 1977 control subjects. Among the studies, 10 focused on gastric cancer [21, 23, 27, 29, 30, $32-34,38,39]$, three focused on breast cancer $[25,35,36]$, two focused on hepatocellular carcinoma [20,37], and one each focused on lung cancer [19], oral squamous cell carcinoma [22], salivary gland tumor [24], nasopharyngeal carcinoma [26], neuroblastoma [28], colorectal cancer [31], and prostate cancer [40]. Of the publications, 12 had quality scores higher than nine, and 10 had quality scores of no more than nine.

\section{Meta-analysis results}

As shown in Table 2, significant heterogeneity was presented in all genetic models. As a result, we adopted a random-effect model for all the analyses. We found the $X P G$ gene rs $751402 \mathrm{C}>\mathrm{T}$ polymorphism associated with increased overall cancer risk (TT vs. CC: odds ratio [OR] $=1.18,95 \%$ confidence interval $[\mathrm{CI}]=1.01-1.38$; $\mathrm{CT}$ vs. $\mathrm{CC}: \mathrm{OR}=1.12,95 \% \mathrm{CI}=1.01-1.24$; and $\mathrm{CT} / \mathrm{TT}$ vs. $\mathrm{CC}$ : $\mathrm{OR}=1.12,95 \% \mathrm{CI}=1.002-1.26$ ). As shown in Figure 2 , stratification analysis indicated that this polymorphism was associated with increased risk of gastric cancer (TT vs. $\mathrm{CC}: \mathrm{OR}=1.38,95 \% \mathrm{CI}=1.12-1.70$; $\mathrm{CT}$ vs. $\mathrm{CC}$ : $\mathrm{OR}$ $=1.14,95 \% \mathrm{CI}=1.05-1.24$; $\mathrm{TT}$ vs. $\mathrm{CC} / \mathrm{CT}: \mathrm{OR}=1.27$, $95 \% \mathrm{CI}=1.06-1.51 ; \mathrm{CT} / \mathrm{TT}$ vs. $\mathrm{CC}: \mathrm{OR}=1.17,95 \% \mathrm{CI}=$ 1.08-1.26; and $\mathrm{T}$ vs. $\mathrm{C}: \mathrm{OR}=1.17,95 \% \mathrm{CI}=1.07-1.27)$ and hepatocellular carcinoma (CT vs. CC: $\mathrm{OR}=1.61$, $95 \% \mathrm{CI}=1.19-2.17$; and $\mathrm{CT} / \mathrm{TT}$ vs. $\mathrm{CC}: \mathrm{OR}=1.53,95 \%$ $\mathrm{CI}=1.10-2.13)$. The stratification analysis did not reveal a significant difference between the two strata in any genetic model by quality score.

\section{False-positive report probability analysis for significant findings}

We performed false-positive report probability (FPRP) analysis for all significant findings and confirmed that the findings were significant at the priority of 0.1 for gastric cancer and hepatocellular carcinoma (Table 3).

\section{The genotype-based mRNA expression for $X P G$ gene rs751402 $\mathrm{C}>\mathrm{T}$ polymorphism}

As shown in Table 4, the rs 751402T allele carriers were associated with decreased $X P G$ mRNA expression among Asians (not significant), Africans (TT vs. CC: $P=$ 0.029 ), and Caucasians (TT vs. CC: $P=0.013$; and TT vs. $\mathrm{CC} / \mathrm{CT}: P=0.011$ ), as well as all subjects (TT vs. CC: $P=$ 0.010 ; and TT vs. CC/CT: $P=0.008$ ).

\section{Sensitivity analysis and publication bias}

By omitting each publication once in every genetic model in the sensitivity analysis, we did not find any individual publication that could significantly alter the pooled ORs, which indicated that our data were stable and trustworthy. As shown in Figure 3, no obvious publication bias was observed for rs751402 $\mathrm{C}>\mathrm{T}$ polymorphism (TT vs. CC: $P=0.111$; CT vs. CC: $P=0.251$; TT vs. CT/CC: $P=0.236$; $\mathrm{CT} / \mathrm{TT}$ vs. $\mathrm{CC}: P=0.249$; and T vs. C: $P=$ $0.298)$.

\section{Trial sequential analysis}

As shown in Figure 4, we observed that the cumulative z-curve crossed the monitoring boundary before reaching the required sample size, indicating the 
Table 1: Characteristics of the included studies in the final meta-analysis

\begin{tabular}{|c|c|c|c|c|c|c|c|c|c|c|c|c|c|c|c|c|c|}
\hline \multirow{2}{*}{ Name } & \multirow{2}{*}{ Year } & \multirow{2}{*}{ Cancer type } & \multirow{2}{*}{ Region } & \multirow{2}{*}{ Ethnicity } & \multirow{2}{*}{ Design } & \multirow{2}{*}{$\begin{array}{l}\text { Genotype } \\
\text { method }\end{array}$} & \multicolumn{4}{|c|}{ Case } & \multicolumn{4}{|c|}{ Control } & \multirow{2}{*}{ MAF } & \multirow{2}{*}{ HWE } & \multirow{2}{*}{ Scor } \\
\hline & & & & & & & $\mathrm{CC}$ & CT & TT & All & $\mathrm{CC}$ & CT & TT & All & & & \\
\hline Shao & 2007 & Lung & China & Asian & $\mathrm{HB}$ & Taqman & 433 & 429 & 105 & 967 & 448 & 425 & 110 & 983 & 0.33 & 0.544 & 11 \\
\hline Yoon & 2011 & $\mathrm{HCC}$ & Taiwan & Asian & HB & Taqman & 33 & 52 & 11 & 96 & 167 & 137 & 32 & 336 & 0.30 & 0.614 & 6 \\
\hline Duan & 2012 & Gastric & China & Asian & $\mathrm{HB}$ & MassARRAY & 172 & 181 & 47 & 400 & 206 & 165 & 29 & 400 & 0.28 & 0.605 & 11 \\
\hline Zavras & 2012 & OSCC & Taiwan & Asian & HB & Taqman & 98 & 110 & 31 & 239 & 167 & 137 & 32 & 336 & 0.30 & 0.614 & 9 \\
\hline $\mathrm{He}$ & 2013 & Gastric & China & Asian & HB & Taqman & 486 & 491 & 148 & 1125 & 560 & 499 & 137 & 1196 & 0.32 & 0.110 & 13 \\
\hline Meng & 2013 & Salivary gland & China & Asian & HB & PCR-RFLP & 59 & 63 & 11 & 133 & 64 & 55 & 23 & 142 & 0.36 & 0.065 & 8 \\
\hline $\mathrm{Na}$ & 2015 & Breast & China & Asian & $\mathrm{HB}$ & PCR-RFLP & 128 & 152 & 45 & 325 & 137 & 147 & 41 & 325 & 0.35 & 0.872 & 10 \\
\hline Sun & 2015 & NPC & China & Asian & $\mathrm{HB}$ & PCR-LDR & 17 & 118 & 237 & 372 & 19 & 117 & 235 & 371 & 0.79 & 0.377 & 11 \\
\hline Chen & 2016 & Gastric & China & Asian & HB & Taqman & 286 & 313 & 93 & 692 & 351 & 331 & 89 & 771 & 0.33 & 0.416 & 11 \\
\hline $\mathrm{He}$ & 2016 & Neuroblastoma & China & Asian & $\mathrm{HB}$ & Taqman & 96 & 114 & 38 & 248 & 208 & 241 & 82 & 531 & 0.38 & 0.380 & 10 \\
\hline Feng & 2016 & Gastric & China & Asian & HB & PCR-RFLP & 70 & 83 & 24 & 177 & 101 & 107 & 28 & 236 & 0.35 & 0.967 & 6 \\
\hline Guo & 2016 & Gastric & China & Asian & HB & PCR-RFLP & 47 & 73 & 22 & 142 & 117 & 136 & 21 & 274 & 0.32 & 0.029 & 5 \\
\hline Hua & 2016 & Colorectal & China & Asian & $\mathrm{HB}$ & Taqman & 792 & 860 & 248 & 1900 & 724 & 952 & 301 & 1977 & 0.39 & 0.680 & 10 \\
\hline Hua & 2016 & Gastric & China & Asian & $\mathrm{HB}$ & Taqman & 426 & 555 & 161 & 1142 & 433 & 551 & 189 & 1173 & 0.40 & 0.537 & 11 \\
\hline $\mathrm{Li}$ & 2016 & Gastric & China & Asian & $\mathrm{HB}$ & PCR-RFLP & 88 & 106 & 22 & 216 & 95 & 103 & 18 & 216 & 0.32 & 0.174 & 8 \\
\hline $\mathrm{Lu}$ & 2016 & Gastric & China & Asian & HB & PCR-RFLP & 69 & 91 & 24 & 184 & 87 & 97 & 22 & 206 & 0.34 & 0.510 & 6 \\
\hline $\mathrm{Ma}$ & 2016 & Breast & China & Asian & HB & PCR-RFLP & 127 & 150 & 43 & 320 & 107 & 101 & 28 & 236 & 0.33 & 0.580 & 7 \\
\hline Wang & 2016 & Breast & China & Asian & HB & PCR-RFLP & 90 & 10 & 1 & 101 & 51 & 39 & 11 & 101 & 0.30 & 0.398 & 9 \\
\hline Wang & 2016 & HCC & China & Asian & PB & MassARRAY & 70 & 81 & 18 & 169 & 232 & 185 & 60 & 477 & 0.32 & 0.018 & 12 \\
\hline Yang & 2016 & Gastric & China & Asian & $\mathrm{HB}$ & PCR-RFLP & 49 & 73 & 33 & 155 & 103 & 111 & 32 & 246 & 0.36 & 0.807 & 6 \\
\hline Zhou & 2016 & Gastric & China & Asian & $\mathrm{HB}$ & PCR-LDR & 174 & 196 & 61 & 431 & 193 & 193 & 46 & 432 & 0.33 & 0.827 & 12 \\
\hline Wang & 2017 & Prostate & China & Asian & HB & Taqman & 442 & 458 & 104 & 1004 & 477 & 467 & 111 & 1055 & 0.33 & 0.834 & 10 \\
\hline
\end{tabular}

MAF, minor allele frequency; HWE, Hardy-Weinberg equilibrium; HCC, hepatocellular carcinoma; OSCC, oral squamous cell carcinoma; NPC, nasopharyngeal carcinoma; HB, hospital based; PB, population based; PCR-RFLP, polymerase chain reaction-restriction fragment length polymorphism; PCR-LDR, polymerase chain reaction- ligase detection reaction.

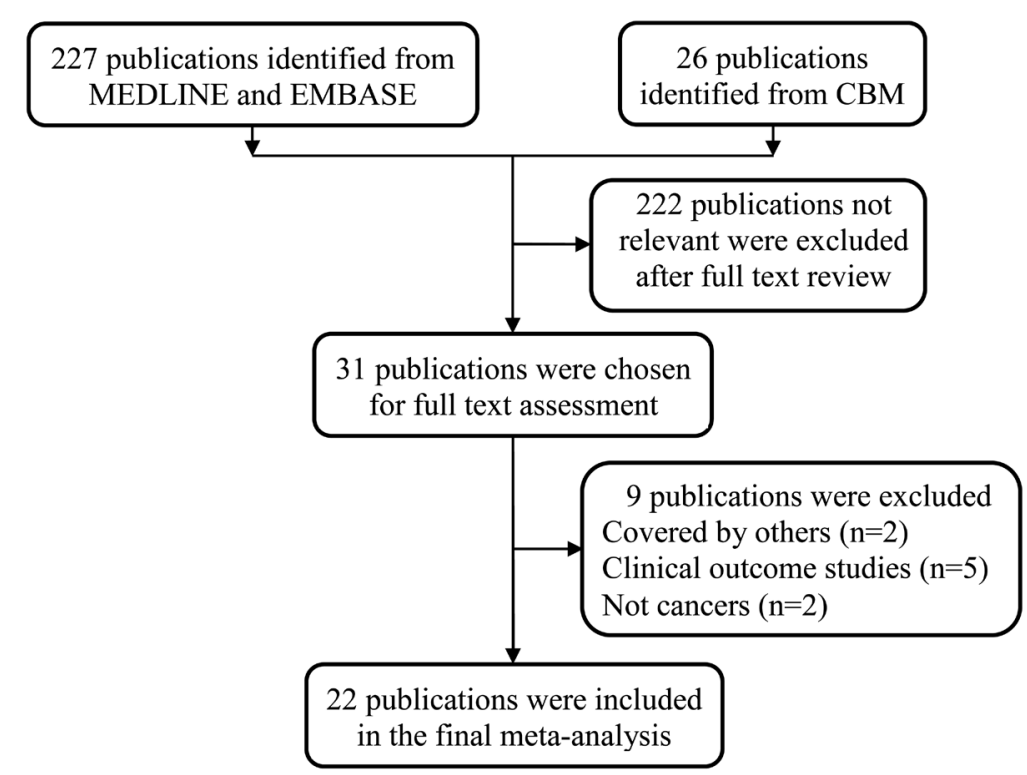

Figure 1: Flowchart of the included publications. 
Table 2: Meta-analysis of the association between $X P G$ gene rs751402 C $>$ T polymorphism and overall cancer risk

\begin{tabular}{|c|c|c|c|c|c|c|c|c|c|c|c|c|}
\hline \multirow{3}{*}{ Variables } & \multirow{3}{*}{$\begin{array}{l}\text { No. of } \\
\text { studies }\end{array}$} & \multirow{3}{*}{ Sample size } & Homozygous & \multirow[b]{3}{*}{$P^{\text {het }}$} & Heterozygous & \multirow[b]{3}{*}{$P^{\text {het }}$} & Recessive & \multirow[b]{3}{*}{$P^{\text {het }}$} & Dominant & \multirow[b]{3}{*}{$P^{\text {het }}$} & Allele & \multirow[b]{3}{*}{$P^{\text {het }}$} \\
\hline & & & TT vs. CC & & CT vs. CC & & TT vs. $\mathbf{C T}+\mathbf{C C}$ & & CT+TT vs. CC & & T vs. C & \\
\hline & & & OR $(95 \%$ CI $)$ & & OR $(95 \%$ CI $)$ & & OR $(95 \% \mathrm{CI})$ & & OR $(95 \%$ CI $)$ & & OR $(95 \%$ CI) & \\
\hline All & 22 & $10538 / 10511$ & $1.18(1.01-1.38)$ & $<0.001$ & $1.12(1.01-1.24)$ & $<0.001$ & $1.09(0.97-1.23)$ & 0.009 & $1.12(1.002-1.26)$ & $<0.001$ & $1.09(1.00-1.18)$ & $<0.001$ \\
\hline \multicolumn{13}{|c|}{ Cancer type } \\
\hline Gastric & 10 & $4664 / 5150$ & $1.38(1.12-1.70)$ & 0.020 & $1.14(1.05-1.24)$ & 0.936 & $1.27(1.06-1.51)$ & 0.053 & $1.17(1.08-1.26)$ & 0.437 & $1.17(1.07-1.27)$ & 0.043 \\
\hline Breast & 3 & $746 / 662$ & $0.79(0.31-1.98)$ & 0.010 & $0.64(0.26-1.58)$ & $<0.001$ & $0.87(0.43-1.79)$ & 0.044 & $0.60(0.23-1.60)$ & $<0.001$ & $0.63(0.29-1.35)$ & $<0.001$ \\
\hline $\mathrm{HCC}$ & 2 & $265 / 813$ & $1.24(0.73-2.12)$ & 0.262 & $1.61(1.19-2.17)$ & 0.373 & $0.96(0.62-1.49)$ & 0.398 & $1.53(1.10-2.13)$ & 0.256 & $1.26(0.97-1.63)$ & 0.220 \\
\hline Others & 7 & $4863 / 5395$ & $0.95(0.78-1.16)$ & 0.082 & $1.03(0.89-1.18)$ & 0.071 & $0.94(0.82-1.07)$ & 0.270 & $1.02(0.88-1.18)$ & 0.028 & $0.99(0.90-1.10)$ & 0.025 \\
\hline \multicolumn{13}{|c|}{ Quality score } \\
\hline$>9$ & 12 & $8775 / 9691$ & $1.08(0.93-1.25)$ & 0.011 & $1.06(0.98-1.17)$ & 0.063 & $1.02(0.92-1.14)$ & 0.137 & $1.08(0.98-1.19)$ & 0.007 & $1.05(0.98-1.14)$ & 0.002 \\
\hline$\leq 9$ & 10 & $1763 / 2329$ & $1.34(0.95-1.89)$ & 0.009 & $1.13(0.86-1.48)$ & $<0.001$ & $1.21(0.90-1.62)$ & 0.029 & $1.12(0.84-1.51)$ & $<0.001$ & $1.07(0.85-1.35)$ & $<0.001$ \\
\hline
\end{tabular}

OR, odds ratio; CI, confidence interval; Het, heterogeneity; HCC, hepatocellular carcinoma.

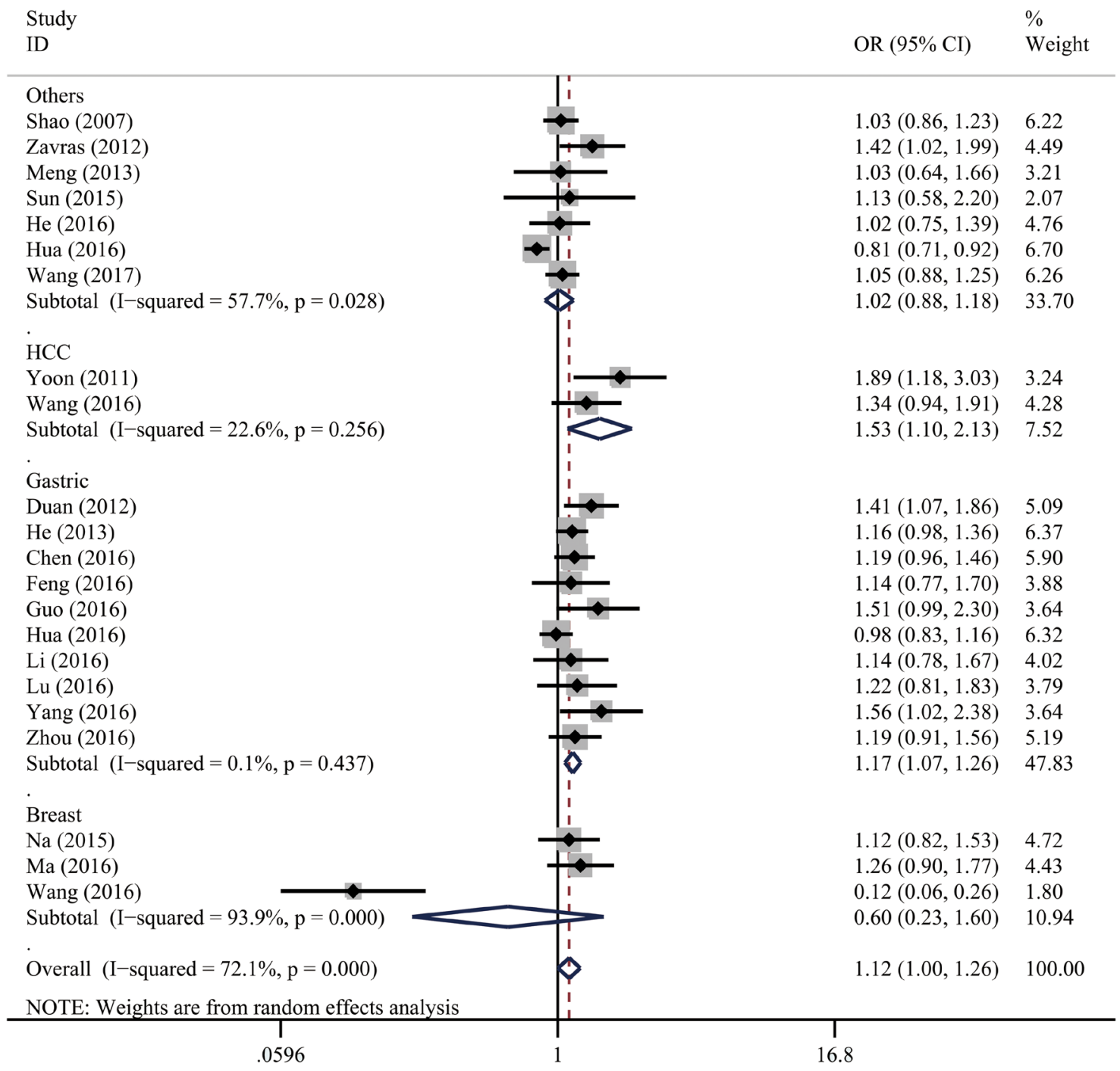

Figure 2: Stratification analysis for the association between $X P G$ gene rs751402 C $>T$ polymorphism and overall cancer risk by cancer type under the dominant model (CT/TT vs. CC). For each publication, the estimation of OR and its $95 \% \mathrm{CI}$ are plotted with a box and a horizontal line. The diamonds represent the pooled ORs and 95\% CIs. 
Table 3: False-positive report probability analysis values for the noteworthy findings

\begin{tabular}{|c|c|c|c|c|c|c|c|c|}
\hline \multirow{2}{*}{ Genotype } & \multirow{2}{*}{$\begin{array}{c}\text { Crude OR } \\
(95 \% \text { CI) }\end{array}$} & \multirow{2}{*}{$P^{a}$} & \multirow{2}{*}{$\begin{array}{c}\text { Statistical } \\
\text { power }^{b}\end{array}$} & \multicolumn{5}{|c|}{ Prior probability } \\
\hline & & & & 0.25 & 0.1 & 0.01 & 0.001 & 0.0001 \\
\hline \multicolumn{9}{|l|}{ Overall cancer risk } \\
\hline TT vs. CC & $1.18(1.01-1.38)$ & 0.040 & 1.000 & 0.107 & 0.264 & 0.798 & 0.976 & 0.998 \\
\hline CT vs. CC & $1.12(1.01-1.24)$ & 0.040 & 1.000 & 0.106 & 0.263 & 0.797 & 0.975 & 0.997 \\
\hline $\mathrm{CT} / \mathrm{TT}$ vs. CC & $1.12(1.002-1.26)$ & 0.047 & 1.000 & 0.123 & 0.296 & 0.822 & 0.979 & 0.998 \\
\hline \multicolumn{9}{|c|}{ Hepatocellular carcinoma } \\
\hline CT vs. CC & $1.61(1.19-2.17)$ & 0.002 & 0.394 & 0.013 & 0.038 & 0.305 & 0.816 & 0.978 \\
\hline CT/TT vs. CC & $1.53(1.10-2.13)$ & 0.011 & 0.608 & 0.050 & 0.137 & 0.636 & 0.946 & 0.994 \\
\hline \multicolumn{9}{|l|}{ Gastric cancer } \\
\hline TT vs. CC & $1.38(1.12-1.70)$ & 0.002 & 1.000 & 0.007 & 0.019 & 0.179 & 0.687 & 0.956 \\
\hline CT vs. CC & $1.14(1.05-1.24)$ & 0.003 & 1.000 & 0.008 & 0.024 & 0.213 & 0.732 & 0.965 \\
\hline TT vs. CT/CC & $1.27(1.06-1.51)$ & 0.010 & 1.000 & 0.030 & 0.085 & 0.506 & 0.912 & 0.990 \\
\hline CT/TT vs. CC & $1.17(1.08-1.26)$ & $<0.001$ & 1.000 & 0.001 & 0.002 & 0.019 & 0.161 & 0.658 \\
\hline T vs. C & $1.17(1.07-1.27)$ & 0.001 & 1.000 & 0.002 & 0.006 & 0.063 & 0.404 & 0.871 \\
\hline
\end{tabular}

OR, odds ratio; $\mathrm{CI}$, confidence interval.

${ }^{\mathrm{a}} \mathrm{A} \chi^{2}$ test was used to evaluate the distributions of genotype frequency.

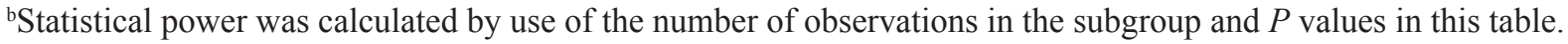

Table 4: XPG gene mRNA expression by the genotypes of $\operatorname{rs} 751402 \mathrm{C}>\mathrm{T}^{\mathrm{a}}$

\begin{tabular}{|c|c|c|c|c|c|}
\hline Population & Genotypes & No. & Mean \pm SD & $P^{b}$ & $P_{\text {trend }} \mathrm{c}$ \\
\hline \multirow{5}{*}{ Asian } & $\mathrm{CC}$ & 30 & $9.79 \pm 0.21$ & & 0.409 \\
\hline & CT & 47 & $9.76 \pm 0.22$ & 0.537 & \\
\hline & $\mathrm{TT}$ & 13 & $9.69 \pm 0.23$ & 0.188 & \\
\hline & Dominant & 60 & $9.75 \pm 0.22$ & 0.352 & \\
\hline & Recessive & 77 & $9.77 \pm 0.22$ & 0.233 & \\
\hline \multirow{5}{*}{$\mathrm{CEU}$} & $\mathrm{CC}$ & 54 & $9.72 \pm 0.23$ & & 0.039 \\
\hline & $\mathrm{CT}$ & 29 & $9.70 \pm 0.22$ & 0.823 & \\
\hline & TT & 7 & $9.48 \pm 0.15$ & 0.013 & \\
\hline & Dominant & 36 & $9.66 \pm 0.22$ & 0.271 & \\
\hline & Recessive & 83 & $9.71 \pm 0.23$ & 0.011 & \\
\hline \multirow{5}{*}{ YRI } & $\mathrm{CC}$ & 35 & $9.86 \pm 0.16$ & & 0.100 \\
\hline & $\mathrm{CT}$ & 43 & $9.82 \pm 0.17$ & 0.245 & \\
\hline & TT & 12 & $9.75 \pm 0.14$ & 0.029 & \\
\hline & Dominant & 55 & $9.80 \pm 0.17$ & 0.094 & \\
\hline & Recessive & 78 & $9.84 \pm 0.17$ & 0.074 & \\
\hline \multirow{5}{*}{ All } & $\mathrm{CC}$ & 119 & $9.78 \pm 0.22$ & & 0.030 \\
\hline & $\mathrm{CT}$ & 119 & $9.77 \pm 0.21$ & 0.693 & \\
\hline & TT & 32 & $9.67 \pm 0.21$ & 0.010 & \\
\hline & Dominant & 151 & $9.75 \pm 0.21$ & 0.220 & \\
\hline & Recessive & 238 & $9.77 \pm 0.21$ & 0.008 & \\
\hline
\end{tabular}

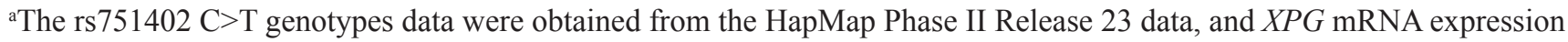
levels were from EBV-transformed lymphoblastoid cell lines from 270 individuals.

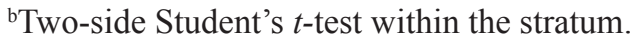

${ }^{c} P$ values for the trend test of the $X P G$ gene mRNA expression among three genotypes for rs $751402 \mathrm{C}>\mathrm{T}$ from a general linear model. 


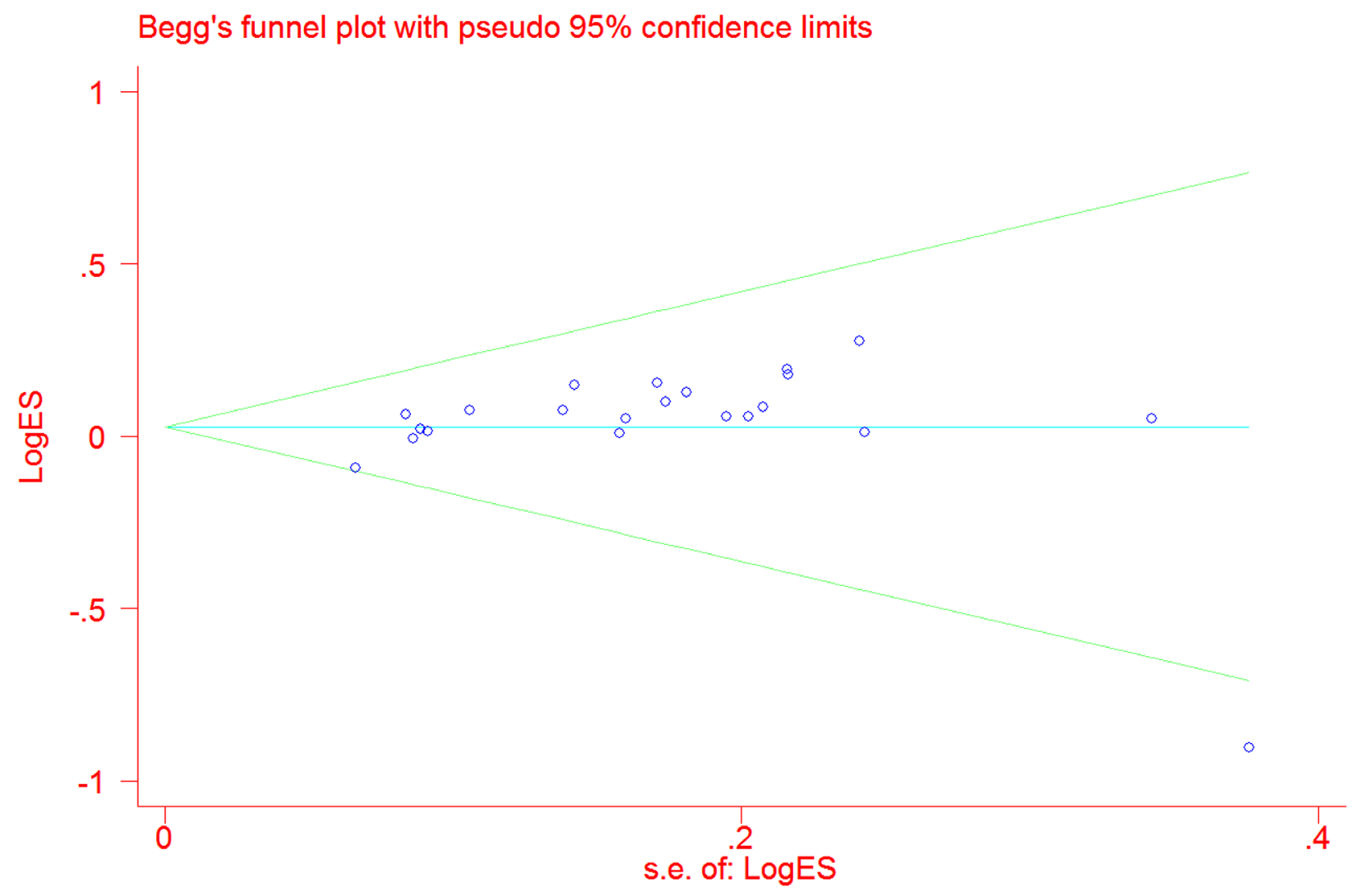

Figure 3: Funnel plot for the association between $X P G$ gene rs751402 $\mathrm{C}>\mathrm{Tpolymorphism}$ and overall cancer risk under the dominant model (CT/TT vs. CC).

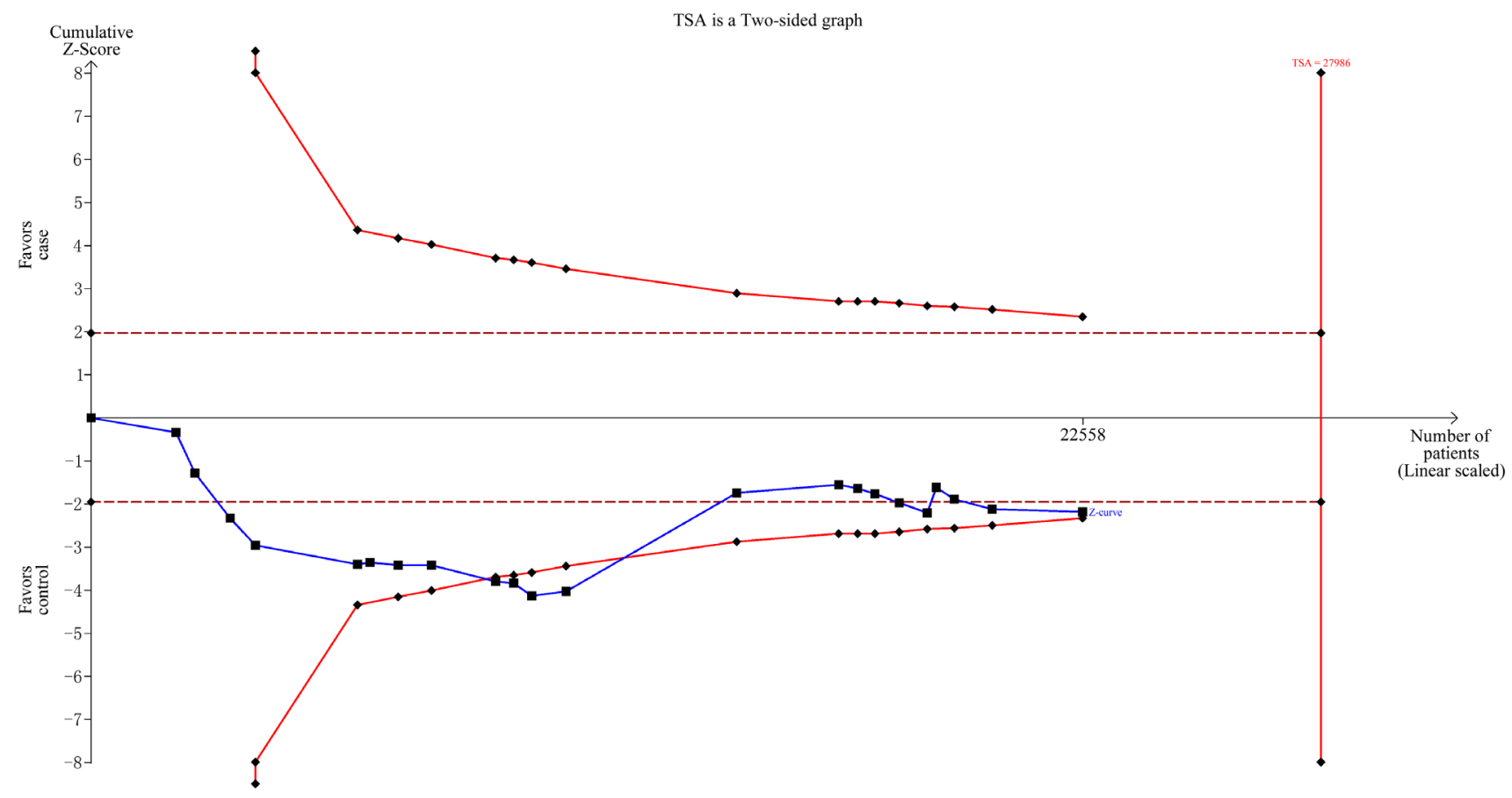

Figure 4: Trial sequential analysis for $X P G$ gene rs751402 $C>T$ polymorphism under the dominant model. 
sample size was sufficient and no further investigation was needed to verify the results.

\section{DISCUSSION}

In the current meta-analysis, we investigated all available publications that contained studies of the association between $X P G$ gene rs751402 C>T polymorphism and cancer risk. The pooled results suggest that this polymorphism is associated with increased cancer risk, especially for gastric cancer and hepatocellular carcinoma.

The $X P G$ gene, which is located at $13 \mathrm{q} 33$ and consists of 15 exons, promotes the removal of damaged DNA in the NER process [41]. When DNA repair capability is decreased, cells might fail to repair the damage. As DNA mutations accumulate, carcinoma might occur $[9,21]$. The $X P G$ gene is an essential component of the NER pathway, and it activates the cleavage of DNA on the $3^{\prime}$ side of the lesion [42]. Studies reported that the $X P G$ gene promotes cellular processes such as RNA polymerase II transcription and transcription-coupled DNA repair [43]. XPG gene polymorphisms might affect the expression or function of the XPG protein. Studies in several publications investigated the function of $X P G$ gene rs751402 $\mathrm{C}>\mathrm{T}$ polymorphism in cancer susceptibility. However, inconsistent results have been reported. Duan et al. [21] found that this polymorphism might increase the risk of gastric cancer in a study of 403 gastric cancer cases and 403 healthy control subjects. This association was also confirmed in gastric cancer by Yang et al. [38] in a study of 155 gastric cancer cases and 246 healthy control subjects, in hepatocellular carcinoma by Yoon et al. [20], and in oral squamous cell carcinoma by Zavras et al. [22]. Hua et al. [31] found that this polymorphism might be associated with decreased colorectal cancer susceptibility by studying 1901 colorectal cases and 1976 control subjects, and might have no effect in gastric cancer, as determined by 1142 cases and 1173 control subjects. Others found that this polymorphism might have weak effects on cancer susceptibility. The controversy can possibly be ascribed to the small sample size as well as cancer differences. To overcome the limitations of a single study and to reduce the likelihood of random errors being responsible for false-positive or false-negative associations, we performed the current meta-analysis to assess the association between XPG gene rs751402 $\mathrm{C}>\mathrm{T}$ polymorphism and overall cancer susceptibility. We included 22 available publications, encompassing 10588 cases and 10511 control subjects, and found that this polymorphism was associated with increased overall cancer risk, especially for gastric cancer and hepatocellular carcinoma. We also performed FPRP analysis to confirm that the significant associations were trustworthy and robust. In addition, the genotype-based mRNA expression analysis as performed also indicated that this polymorphism might be associated with $X P G$ gene mRNA expression alteration.

The current meta-analysis has five advantages. First, we searched the latest publications and we also included the publications written in Chinese. Second, we assessed the quality of each investigation and conducted stratification analysis by the quality score to search for publication bias. Third, we performed genotype-based mRNA expression analysis to provide further evidence that the rs751402 $\mathrm{C}>\mathrm{T}$ polymorphism can influence the expression of the $X P G$ gene. Fourth, we performed FPRP analysis, which can confirm whether the significant associations are trustworthy and robust. Fifth, we performed TSA to strengthen the robustness and minimize random errors of our conclusions.

Although in the present study we performed the latest and largest meta-analysis for assessing the association between XPG gene rs751402 C>T polymorphism and overall cancer susceptibility, four limitations must be considered. First, because of the heterogeneity in the current meta-analysis, the conclusions on the overall cancer risk should be interpreted cautiously. Second, the results of this study were based on the unadjusted ORs, which might suppress the final results. Third, all the study subjects were Asians. Other ethnicities are needed as subjects in future studies. Fourth, despite the adequacy of the total number of publications, the number of publications that contain studies for some cancers were inadequate. Investigations into other cancers are needed.

Our meta-analysis found that XPG gene rs751402 $\mathrm{C}>\mathrm{T}$ polymorphism is associated with increased overall cancer risk, especially with respect to gastric cancer and hepatocellular carcinoma. Investigations of different cancers and ethnicities are needed to validate our findings.

\section{MATERIALS AND METHODS}

\section{Publication search}

We systematically searched publications from the MEDLINE, EMBASE, and CBM databases (the last search was updated April 28, 2017) using the following search terms: "cancer or carcinoma or tumor or neoplasm," "excision repair cross-complementing group 5 or ERCC 5 or xeroderma pigmentosum group $\mathrm{G}$ or XPG or rs751402," and "polymorphism or variant or single nucleotide polymorphism (SNP) or variation." We also manually searched the reference lists of the articles in the included publications.

\section{Inclusion and exclusion criteria}

The studies in the included publications met the following criteria: (1) the study evaluated the association between XPG gene rs751402 $\mathrm{C}>\mathrm{T}$ polymorphism and cancer risk, (2) the study was on human beings, (3) the 
study was a case-control or cohort design, (4) sufficient data were provided to calculate the ORs and $95 \%$ CIs, and (5) the study was published in English or Chinese.

Exclusion criteria were (1) the study was not a casecontrol design, (2) the study was duplicated from previous studies, (3) articles were case reports or review articles, and (4) the studies were without detailed genotype data.

\section{Data extraction and quality assessment}

Two authors (Haixia Zhou and Ting-Yan Shi) performed the publication search and data extraction independently. The extracted information includes surname of the first author, publication year, cancer type, country of origin, ethnicity, genotyping methods, and numbers of cases and control subjects with rs751402 CC, CT and TT genotypes. We assessed the quality of each publication based on the quality score assessment [44]. All contradictory information was discussed and resolved through consensus when necessary.

\section{Genotype-based mRNA expression analysis}

To determine whether the $X P G$ gene rs751402 C>T polymorphism can influence expression of the $X P G$ gene, we conducted genotype-based mRNA expression analysis as previously described $[3,45,46]$. Genotype data of $X P G$ gene rs751402 $\mathrm{C}>\mathrm{T}$ polymorphism for 270 individuals were obtained from HapMap Phase II Release 23. The mRNA expression data for the corresponding individuals were from SNPexp [47].

\section{Statistical analysis}

Pooled ORs and 95\% CIs were used to investigate the strength of the association between XPG gene rs751402 $\mathrm{C}>\mathrm{T}$ polymorphism and overall cancer risk under the homozygous (TT vs. CC), heterozygous (CT vs. $\mathrm{CC}$ ), recessive (TT vs. $\mathrm{CT}+\mathrm{CC})$, dominant $(\mathrm{CT}+\mathrm{TT}$ vs. $\mathrm{CC}$ ), and allele contrast (T vs. C) models. A goodnessof-fit $\chi^{2}$ test was adopted to assess the Hardy-Weinberg equilibrium for the control subjects. Stratification analysis was carried out by cancer type (publications with no more than two were merged as the Others Group) and quality score $(>9$ and $\leq 9)$. Heterogeneities were assessed by $\chi^{2}-$ based Q test, and a fixed-effect model was adopted when $P>0.1$. Otherwise, the random-effect model was applied [48]. Sensitivity analysis was then conducted by omitting each publication in turn to evaluate the stability of the overall results. Potential publication bias was assessed by Begg's funnel plot [49] and Egger's linear regression test [50]. FPRP and TSA were as previously described [8]. All the statistics were two-sided, and $P<0.05$ was statistically significant. All statistical analyses were performed by the STATA software (Version 11.0; Stata Corporation, College Station, TX).

\section{CONFLICTS OF INTEREST}

The authors declare that there are no conflicts of interest.

\section{FUNDING}

This study was supported by a grant awarded by the Scientific Research Foundation of Wenzhou (2015Y0492), Zhejiang Provincial Medical and Health Science and Technology plan (2009A148), Zhejiang Provincial Science and Technology Animal Experimental Platform Project (016C37113) and the Special Financial Grant with the China Postdoctoral Science Foundation (2014T70836).

\section{REFERENCES}

1. Torre LA, Bray F, Siegel RL, Ferlay J, Lortet-Tieulent J, Jemal A. Global cancer statistics, 2012. CA Cancer J Clin. 2015; 65:87-108.

2. Chen W, Zheng R, Baade PD, Zhang S, Zeng H, Bray F, Jemal A, Yu XQ, He J. Cancer statistics in China, 2015. CA Cancer J Clin. 2016; 66:115-132.

3. He J, Shi TY, Zhu ML, Wang MY, Li QX, Wei QY. Associations of Lys939Gln and Ala499Val polymorphisms of the XPC gene with cancer susceptibility: a meta-analysis. Int J Cancer. 2013; 133:1765-1775.

4. Xue WQ, He YQ, Zhu JH, Ma JQ, He J, Jia WH. Association of BRCA2 N372H polymorphism with cancer susceptibility: a comprehensive review and meta-analysis. Sci Rep. 2014; 4:6791.

5. Xue W, Zhu M, Wang Y, He J, Zheng L. Association between PLCE1 rs2274223 A> G polymorphism and cancer risk: proof from a meta-analysis. Sci Rep. 2015; 5:7986.

6. Wang Y, Wu XS, He J, Ma T, Lei W, Shen ZY. A novel TP53 variant (rs78378222 A > C) in the polyadenylation signal is associated with increased cancer susceptibility: evidence from a meta-analysis. Oncotarget. 2016; 7:3285432865. https://doi.org/10.18632/oncotarget.9056.

7. Xu C, Zhu J, Fu W, Liang Z, Song S, Zhao Y, Lyu L, Zhang A, He J, Duan P. MDM4 rs4245739 A > C polymorphism correlates with reduced overall cancer risk in a metaanalysis of 69477 subjects. Oncotarget. 2016; 7:7171871726. https://doi.org/10.18632/oncotarget.12326.

8. Fu W, Zhuo ZJ, Chen YC, Zhu J, Zhao Z, Jia W, Hu JH, Fu K, Zhu SB, He J, Liu GC. NFKB1 -94insertion/deletion ATTG polymorphism and cancer risk: Evidence from 50 case-control studies. Oncotarget. 2017; 8:9806-9822. https://doi.org/10.18632/oncotarget.14190.

9. Li C, Wang LE, Wei Q. DNA repair phenotype and cancer susceptibility--a mini review. Int J Cancer. 2009; 124:999-1007.

10. Qian X, Tan H, Zhang J, Liu K, Yang T, Wang M, Debinskie W, Zhao W, Chan MD, Zhou X. Identification of 
biomarkers for pseudo and true progression of GBM based on radiogenomics study. Oncotarget. 2016; 7:55377-55394. https://doi.org/10.18632/oncotarget.10553.

11. Wood RD, Mitchell M, Sgouros J, Lindahl T. Human DNA repair genes. Science. 2001; 291:1284-1289.

12. Gillet LC, Scharer OD. Molecular mechanisms of mammalian global genome nucleotide excision repair. Chem Rev. 2006; 106:253-276.

13. Friedberg EC. How nucleotide excision repair protects against cancer. Nat Rev Cancer. 2001; 1:22-33.

14. He BS, Xu T, Pan YQ, Wang HJ, Cho WC, Lin K, Sun HL, Gao TY, Wang SK. Nucleotide excision repair pathway gene polymorphisms are linked to breast cancer risk in a Chinese population. Oncotarget. 2016; 7:84872-84882. https://doi.org/10.18632/oncotarget.12744.

15. Sugasawa K. Xeroderma pigmentosum genes: functions inside and outside DNA repair. Carcinogenesis. 2008; 29:455-465.

16. Zhu ML, Wang M, Cao ZG, He J, Shi TY, Xia KQ, Qiu LX, Wei QY. Association between the ERCC5 Asp1104His polymorphism and cancer risk: a meta-analysis. PLoS One. 2012; 7:e36293.

17. He XF, Liu LR, Wei W, Liu Y, Su J, Wang SL, Shen XL, Yang XB. Association between the XPG Asp1104His and XPF Arg415Gln polymorphisms and risk of cancer: a metaanalysis. PLoS One. 2014; 9:e88490.

18. Huang J, Liu X, Tang LL, Long JT, Zhu J, Hua RX, Li J. XPG gene polymorphisms and cancer susceptibility: evidence from 47 studies. Oncotarget. 2017; 8:3726337277. https://doi.org/10.18632/oncotarget.16146.

19. Shao MH. (2007). [Association between nucleotide excision repair genes and lung cancer risk]. [Article in Chinese]. Fudan University.

20. Yoon AJ, Kuo WH, Lin CW, Yang SF. Role of ERCC5 polymorphism in risk of hepatocellular carcinoma. Oncol Lett. 2011; 2:911-914.

21. Duan Z, He C, Gong Y, Li P, Xu Q, Sun LP, Wang Z, Xing $C$, Yuan Y. Promoter polymorphisms in DNA repair gene ERCC5 and susceptibility to gastric cancer in Chinese. Gene. 2012; 511:274-279.

22. Zavras AI, Yoon AJ, Chen MK, Lin CW, Yang SF. Association between polymorphisms of DNA repair gene ERCC5 and oral squamous cell carcinoma. Oral Surg Oral Med Oral Pathol Oral Radiol. 2012; 114:624-629.

23. He J. (2013). [Polymorphisms in nucleotide excision repair genes and gastric cancer risk]. [Article in Chinese]. Fudan University.

24. Meng X, Wang QX, Chen MY, Qin G, Wang YP, Liu WX. [DNA repair gene polymorphisms in ERCC4 rs6498486 and ERCC5 rs751402 and risk of salivary gland tumors]. [Article in Chinese]. Shanghai Kou Qiang Yi Xue. 2013; 22:438-442.

25. Na N, Dun E, Ren L, Li G. Association between ERCC5 gene polymorphisms and breast cancer risk. Int J Clin Exp Pathol. 2015; 8:3192-3197.
26. Sun Z. (2015). [The study of the rationship between XPG gene polymorphism and sensitivity of chemotherapy for nasopharyngeal carcinoma]. [Article in Chinese]. Nanchang University.

27. Chen YZ, Guo F, Sun HW, Kong HR, Dai SJ, Huang SH, Zhu WW, Yang WJ, Zhou MT. Association between XPG polymorphisms and stomach cancer susceptibility in a Chinese population. J Cell Mol Med. 2016; 20:903-908.

28. He J, Wang F, Zhu J, Zhang R, Yang T, Zou Y, Xia H. Association of potentially functional variants in the XPG gene with neuroblastoma risk in a Chinese population. $\mathrm{J}$ Cell Mol Med. 2016; 20:1481-1490.

29. Feng YB, Fan DQ, Yu J, Bie YK. Association between XPG gene polymorphisms and development of gastric cancer risk in a Chinese population. Genet Mol Res. 2016; 15. https:// doi.org/10.4238/gmr.15027877.

30. Guo BW, Yang L, Zhao R, Hao SZ. Association between ERCC5 gene polymorphisms and gastric cancer risk. Genet Mol Res. 2016; 15. https://doi.org/10.4238/gmr.15027828.

31. Hua RX, Zhuo ZJ, Zhu J, Zhang SD, Xue WQ, Zhang JB, Xu HM, Li XZ, Zhang PF, He J, Jia WH. XPG Gene Polymorphisms Contribute to Colorectal Cancer Susceptibility: A Two-Stage Case-Control Study. J Cancer. 2016; 7:1731-1739.

32. Hua RX, Zhuo ZJ, Zhu J, Jiang DH, Xue WQ, Zhang SD, Zhang JB, Li XZ, Zhang PF, Jia WH, Shen GP, He J. Association between genetic variants in the XPG gene and gastric cancer risk in a Southern Chinese population. Aging (Albany NY). 2016; 8:3311-3320. https://doi.org/10.18632/ aging. 101119.

33. Li RJ, Li M, Liu GJ, Guo YW, Bai H, Xiao P, Mei JZ. Association between ERCC5 gene polymorphisms and gastric cancer risk in a Chinese population. Genet Mol Res. 2016; 15. https://doi.org/10.4238/gmr.15017510.

34. Lu JJ, Zhang HQ, Mai P, Ma X, Chen X, Yang YX, Zhang LP. Lack of association between ERCC5 gene polymorphisms and gastric cancer risk in a Chinese population. Genet Mol Res. 2016; 15. https://doi. org/10.4238/gmr.15027779.

35. Ma SH, Ling FH, Sun YX, Chen SF, Li Z. Investigation on the role of XPG gene polymorphisms in breast cancer risk in a Chinese population. Genet Mol Res. 2016; 15. https:// doi.org/10.4238/gmr.15028066.

36. Wang H, Wang T, Guo H, Zhu G, Yang S, Hu Q, Du Y, Bai X, Chen X, Su H. Association analysis of ERCC5 gene polymorphisms with risk of breast cancer in Han women of northwest China. Breast Cancer. 2016; 23:479-485.

37. Wang B, Xu Q, Yang HW, Sun LP, Yuan Y. The association of six polymorphisms of five genes involved in three steps of nucleotide excision repair pathways with hepatocellular cancer risk. Oncotarget. 2016; 7:20357-20367. https://doi. org/10.18632/oncotarget.7952.

38. Yang LQ, Zhang Y, Sun HF. Investigation on ERCC5 genetic polymorphisms and the development of gastric 
cancer in a Chinese population. Genet Mol Res. 2016; 15. https://doi.org/10.4238/gmr.15038364.

39. Zhou RM, Niu CX, Wang N, Liu L, Huang X, Chen ZF, Huo XR, Hao YL, Li Y. XPG Gene Polymorphisms and the Risk of Gastric Cardia Adenocarcinoma. Genet Test Mol Biomarkers. 2016; 20:432-437.

40. Wang M, Li Q, Gu C, Zhu Y, Yang Y, Wang J, Jin L, He J, Ye D, Wei Q. Polymorphisms in nucleotide excision repair genes and risk of primary prostate cancer in Chinese Han populations. Oncotarget. 2017; 8:24362-24371. https://doi. org/10.18632/oncotarget.13848.

41. Fagbemi AF, Orelli B, Scharer OD. Regulation of endonuclease activity in human nucleotide excision repair. DNA Repair (Amst). 2011; 10:722-729.

42. Scharer OD. XPG: its products and biological roles. Adv Exp Med Biol. 2008; 637:83-92.

43. Lee SK, Yu SL, Prakash L, Prakash S. Requirement of yeast RAD2, a homolog of human XPG gene, for efficient RNA polymerase II transcription. implications for Cockayne syndrome. Cell. 2002; 109:823-834.

44. He J, Liao XY, Zhu JH, Xue WQ, Shen GP, Huang SY, Chen W, Jia WH. Association of MTHFR C677T and A1298C polymorphisms with non-Hodgkin lymphoma susceptibility: evidence from a meta-analysis. Sci Rep. 2014; 4:6159.

45. He J, Xi B, Ruiter R, Shi TY, Zhu ML, Wang MY, Li QX, Zhou XY, Qiu LX, Wei QY. Association of LEP G2548A and LEPR Q223R polymorphisms with cancer susceptibility: evidence from a meta-analysis. PLoS One. 2013; 8:e75135.

46. Shi TY, He J, Wang MY, Zhu ML, Yu KD, Shao ZM, Sun MH, Wu X, Cheng X, Wei Q. CASP7 variants modify susceptibility to cervical cancer in Chinese women. Sci Rep. 2015; 5:9225.

47. Holm K, Melum E, Franke A, Karlsen TH. SNPexp - A web tool for calculating and visualizing correlation between HapMap genotypes and gene expression levels. BMC Bioinformatics. 2010; 11:600.

48. Higgins JP, Thompson SG. Quantifying heterogeneity in a meta-analysis. Stat Med. 2002; 21:1539-1558.

49. Begg CB, Mazumdar M. Operating characteristics of a rank correlation test for publication bias. Biometrics. 1994; 50:1088-1101.

50. Egger M, Davey Smith G, Schneider M, Minder C. Bias in meta-analysis detected by a simple, graphical test. BMJ. 1997; 315:629-634. 